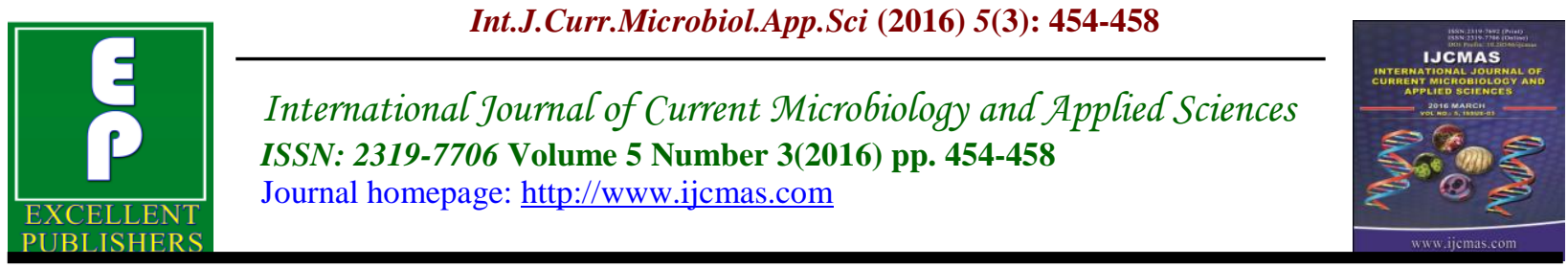

Original Research Article

http://dx.doi.org/10.20546/ijcmas.2016.503.053

\title{
Prevalence of Rotavirus Acute Gastroenteritis in Infants
}

\author{
D. Kavitha*, K. Kanimozhi and A. Pannerselvam \\ Department of Botany \& Microbiology, A.V.V.M.Sri Pushpam College (Autonomous), \\ Poondi- 613503, Thanjavur, Tamilnadu, India \\ *Corresponding author
}

\begin{tabular}{|c|c|}
\hline & A B S T R A C T \\
\hline $\begin{array}{l}\text { Ke y w o r d s } \\
\text { Rotavirus, } \\
\text { Diarrhoea, } \\
\text { Prevalence, } \\
\text { Rotavirus } \\
\text { Gastroenteritis, } \\
\text { Children. }\end{array}$ & $\begin{array}{l}\text { Rotavirus is a common cause of diarrhoea in children. There is a need for data on } \\
\text { prevalence of rotavirus diarrhoea especially in our territory. This study was carried } \\
\text { out to study the prevalence of rotavirus infection in children upto one year } \\
\text { presenting with diarrhoea with rotavirus infection in them. A perspective } \\
\text { observational study was carried out to study the prevalence of rotavirus infection } \\
\text { amongst children up to one year presenting with diarrhoea. The clinical profile of } \\
\text { the children was analysed along with detection of rotavirus antigen in stool. A total } \\
\text { of } 35 \text { children ( } 26 \text { male and } 9 \text { female) with diarrhoea were included in the study. } 19\end{array}$ \\
\hline Article Info & cases $(54 \%)$ (13 male $(68 \%)$ and 6 female infants $(32 \%)$ were infected with \\
\hline $\begin{array}{l}\text { Accepted: } \\
18 \text { February } 2016 \\
\text { Available Online: } \\
10 \text { March } 2016\end{array}$ & $\begin{array}{l}\text { Rotavirus Gastroenteritis. The remaining } 16 \text { infants }(46 \%) \text { were infected with other } \\
\text { than Rotavirus Gastroenteritis. The prevalence of rotavirus infection was } 54 \% \text { in } \\
\text { our territory. Also observed that male children were predominantly infected with } \\
\text { rotavirus. }\end{array}$ \\
\hline
\end{tabular}

\section{Introduction}

Rotavirus is member of the genus rotavirus, family Reoviridae, and it is important causative agent of acute gastroenteritis in children and in many young animal species worldwide (Dulgheroff A C et all. 2014). There are five species of this virus, referred to as $\mathrm{A}, \mathrm{B}, \mathrm{C}, \mathrm{D}$, and E. Rotavirus $\mathrm{A}$, the most common species, causes more than $90 \%$ of infections in humans (Dennehy $\mathrm{P}$ H2000).Approximately 1.5 million deaths due to Diarrheal disorders estimated globally every year making it the second leading cause of childhood mortality (Bhutta Zulfiqar Ahmed, 2011). Human Rotavirus is recognized as one of the most common causes of non-bacterial acute gastroenteritis
(AGE) among infants and children worldwide (Parashar UD et al., 2006, Rheingan RD et al., 2006, Osonuga A et al., 2013). Rotavirus infection ranges from asymptomatic infection to severe life threatening diarrhoea. It has been estimated that $29 \%$ of all diarrheal deaths in children $<5$ years of age is due to rotavirus and about $23 \%$ of rotavirus deaths are in the Indian subcontinent (Tate JE et al.,2012, WgCdr B.M. John et al., 2014). Nearly every child in the world has been infected with rotavirus at least once by age five (Mwenda JM et al., 2012).Rotavirus infection affects $95 \%$ of children under the age of 5 years regardless 
of the socio-economic or environmental conditions and leads more frequently to dehydration than other etiologies (World Health Organization 2000-2011, Banerjee I et al., 2006; Chakravarti A et al., 2010). There is very poor documentation in our population in this regard. Hence, there is a need for acquiring data on prevalence of rotavirus diarrhea especially in our setting is inevitable. The present study has been carried out with this background to add to the existing knowledge on the magnitude of the problem in our population.

\section{Materials and Methods}

The study was conducted in a private diagnostic laboratory and Research center in Tiruchirappalli. It is a multifacilitated research laboratory, receives a daily average of patients from 250-500. The study population includes children $\leq$ one year old who were attending the laboratory for investigation and diagnosed as rotavirus suspected cases during three months. Relevant data such as gender, age, residence, dehydration status, time of diagnosis, management, were collected from records of the three months January to March 2015. All children's parents given consent and this study approved by local ethics committee.

\section{Sample Collection}

35 diarrhoeal faeces samples were collected in a clean wide mouthed container from the infants with unknown source of Gastroenteritis during the month of January to March 2015. All the samples were taken for analysis within 30 minutes to one hour of collection.

\section{Qualitative Method}

All the reagents provided in the kit were allowed to reach room temperature before analysis. About 0.2 grams of faecal specimen was added to $2 \mathrm{ml}$ of prepared $1 \mathrm{x}$ extraction buffer. The contents were mixed on a vortex mixer for homogenous suspension and incubated in room temperature for 10 minutes. The contents were centrifuged at $1000 \mathrm{rpm}$ for 10 minutes after incubation period. 2 drops were taken from extraction buffer and delivered to circle 1 and 2. A drop of control latex reagent was added to circle and Test latex reagent was added to circle 2. Both the contents were titled with 2 different application stick separately for every 2 seconds up to 2 minutes.

\section{Results and Discussion}

\section{Percentage of Rotavirus Infected Children}

Among 35 infants with Gastroenteritis diarrhea 26 male infants and 9 girl infants were involved in this project. The positive results were observed with visible agglutination of test latex particles in few seconds depending on the strength of the viral extract.

The negative results were observed with milky appearance without any visible agglutination of the latex particles. Strong agglutination with test latex first indicates a positive result. Only strong agglutination is significant, weak and granular reaction with control latex should be ignored. $54 \%$ of the infants (19 cases) were infected with Rotavirus Gastroenteritis. The remaining 16 infants (46\%) were infected with other than Rotavirus Gastroenteritis. The results obtained are shown in Figure 1.

\section{Age and Sex Distribution of Rotavirus Gastroenteritis}

Among 19 Rotavirus Gastroenteritis, 13 male $(68 \%)$ and 6 female infants (32\%) 
were found to be infected (Fig.2a). Among 13 infected male infants, 4 patients $(31 \%)$ were aged below 6 months while the remaining 9 infants were aged 6 months to below 1 year (69\%) (Fig.2b). Among 6 girl infants 3 of them were below and remaining 3 of them were above 6 months (Fig.2c).

\section{Figure.1 Percentage of Rotavirus Infected Children}

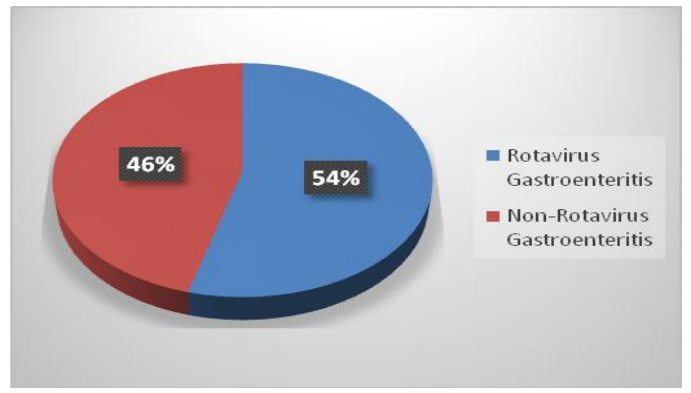

Figure.2 a.Sex Distribution, b.Male-Age Wise and c. Female-Age Wise
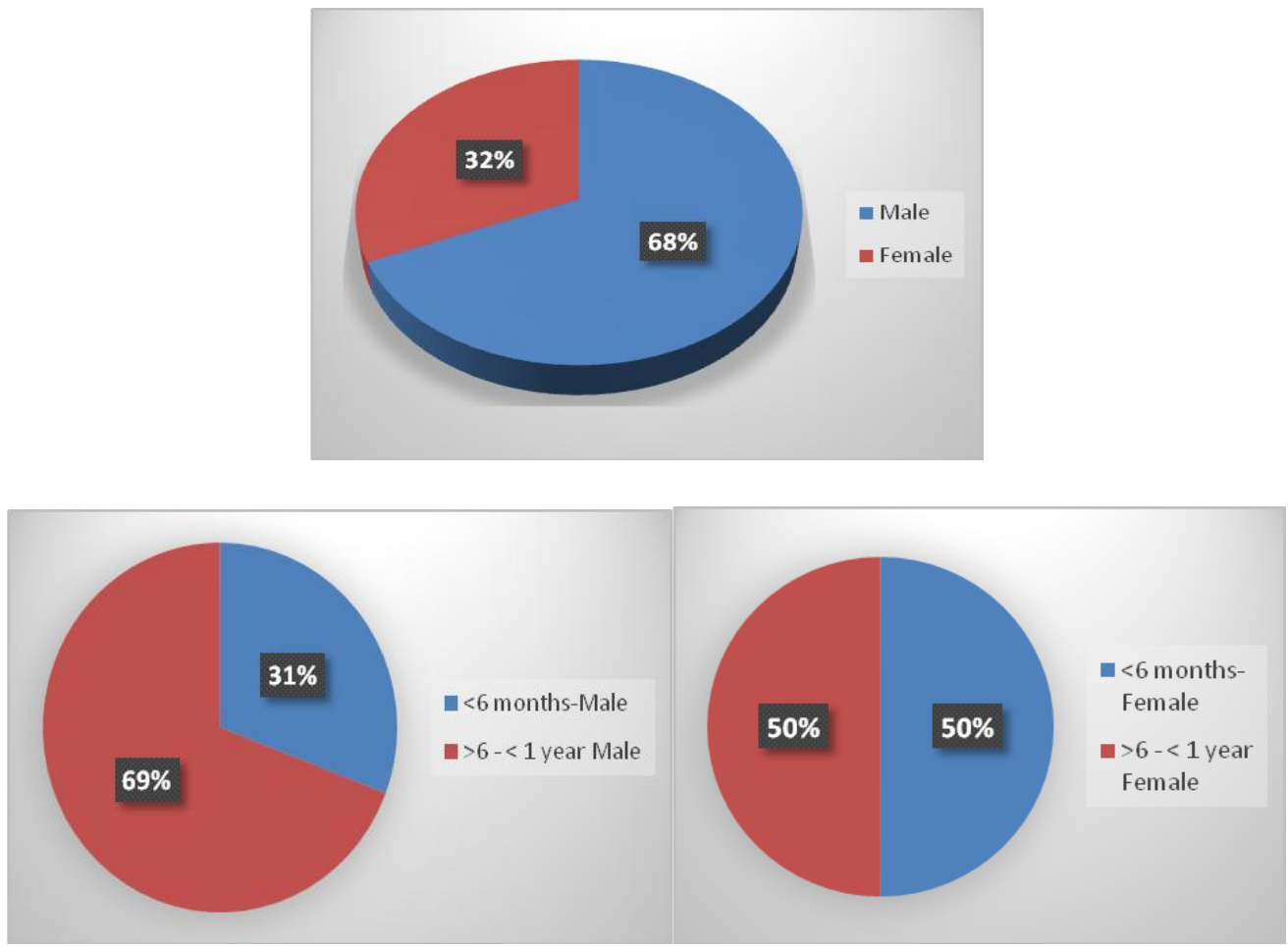

Rotavirus diarrhoea appears to be a major public health problem for children (Bonkoungou et al., 2010) in Tiruchirappalli, as in the other developing countries. Our results show that a significant proportion of acute diarrhoea is due to rotavirus $(54 \%)$ and rotavirus may be responsible for almost half of all hospitalizations for diarrhea in children $<5$ years of age in Tiruchirappalli. Children usually are susceptible group to many infectious diseases. They are being the first victims of any contamination of water and food. Our study was done about recorded cases of rotavirus among children up to one year. In a study conducted in Ghana on 
prevalence of severe acute rotavirus gastroenteritis during two years of the study, 16,348 children younger than five years were hospitalized, and $13.1 \%$ (2147) of these cases were due to acute gastroenteritis (Christabel C E et al., 2012). Also the findings illustrated that male children were more infected with rotavirus than females; however there is no significance to biological or behavioral differences. The present study also observed the similar kind of results. Approximately, $57.5 \%$ of rotavirus cases were males. It is similar to data obtained from Iran that $57.8 \%$ of rotavirus cases were males (Tehereh $\mathrm{Z} \mathrm{K}$ et al., 2013). In a study conducted in different hospitals in Sudan, Magzoub et al found that $65.3 \%$ of studied children were males (Magzoub A M et al., 2013).In the present study, all the cases occurred among age group 1-12 months, it is similar to data obtained in Oman that most of rotavirus positive cases were at 7-12 months of age (Ebtihag, E M et al., 2011). Also Erin et al mentioned that $65 \%-85 \%$ of children hospitalized due to rotavirus disease in the first year of life (Erin M K et al., 2004).

In conclusion, the overall findings of this study showed that rotavirus is one of the major etiological agents of diarrhea seen in infants. Rotavirus Gastroenteritiswas prevalent in 7-12 months old male children and up to 12 months old female children are more susceptible to rotavirus infection.

\section{Acknowledgement}

Our thanks to Doctor's Diagnostic Laboratory and Research Institute, Tiruchirappalli for the permission and assistance to complete this work.

\section{References}

Dulgheroff, A.C., Figueiredo, E.F., Gouve, V.S., Domingues, A.L. 2014. Changes in epidemiology of rotavirus in the Tria nguloMineiro region of Brazil: lack of two consecutive rotavirus seasons. Brazilian J. Med. Biol. Res., 47(12): 1091-1095.

Dennehy, P.H. 2000. Transmission of rotavirus and other enteric pathogens in the home. Pediatric. Infect. Dis. J., 19(10 Suppl): 103-105.

Bhutta Zulfiqar Ahmed. 2011. Acute gastroenteritis in children. In: Kliegman RM, Stanton BF, St Geme JW, Schor NF, Behrman RE, eds. Nelson Text Book of Pediatrics. 19th ed.Philadelphia. WB Saunders Co, 1323-1339.

Parashar, U.D., Gibson, C.J., Bresse, J.S., Glass, R.I. 2006. Rotavirus and severe childhood diarrhea. Emerging Infect. Dis., 12(2): 304-6.

Rheingan, R.D., Heylen, J., Giaquinto, C. 2006. Economics of rotaviuses gastroenteritis and Vaccines in Europe. Pediatr. Infect. Dis. J., 25: 48-55.

Osonuga, A., Osonuga, O.A., Emegoakor, C. 2013. A Review of Current Practices for Management of Rotavirus Infection in Children Under - 5 Years in Ghana. Int. J. Sci. Study., 1(2): 40-44.

Tate, J.E., Burton, A.H., Boschi-Pinto, C., et al. 2012. 2008 estimate of worldwide rotavirus-associated mortality in children younger than 5 years before the introduction of universal rotavirus vaccination programmes: a systematic review and metaanalysis. Lancet Infect. Dis., 12: 136-141.

WgCdr, B.M. John, Col Amit Devgan, Maj BarnaliMitra. 2014. Prevalence of rotavirus infection in children below two years presenting with diarrhea. Med. J. Armed Forces India, 70: 116119. 
Mwenda, J.M., Ntoto, K.M., Abebe, A., Enweronu-Laryea, C., Amina, I., Mchomvu, J. et al. 2012. Burden and epidemiology of rotavirus diarrhea in selected African countries: preliminary results from the African Rotavirus Surveillance Network. J. Infect. Dis., 202Suppl: S5-S11.

World Health Organization. WHO. Global Health Estimates for Deaths by Cause, Age, and Sex for Years 2000-2011. Geneva: Available at: http://www.who.int/healthinfo/global_ health_estimates/en/.

Banerjee, I., Ramani, S., Primrose, B., et al. 2006. Comparative study of the epidemiology of rotavirus in children from a community based birth cohort and a hospital in south India. J. Clin. Microbiol., 44: 2468-2474.

Chakravarti, A., Chauhan, M.S., Sharma, A., Verma, V. 2010. Distribution of human rotavirus $\mathrm{G}$ and $\mathrm{P}$ genotypes in a hospital setting from northern India. Southeast Asian J. Trop. Med. Public Health, 41: 1145-1152.

Bonkoungou, et al. 2010. Epidemiology of rotavirus infection among young children with acute diarrhoea in Burkina Faso. BMC Pediatrics, 10: 94.
Christabel, C.E., Kwamena, W.C., Hope, G., Richard, H.A., Julius, A.M., George, E.A. 2012. Prevalence of severe acute rotavirus gastroenteritis and intussusceptions in Ghanaian children under 5 years of age. J. Infect. Dev. Ctries, 6(2): 14-155.

Tehereh, Z.K., Ahmed, S., Gholamreza, K., Manoochehr, M. 2013. Relative Frequency of Rotavirus and Adenovirus among Children Aged 160 Months Hospitalized With Acute Diarrhea in South Western Iran. Jundishapur J. Microbial., 6(1): 4750.

Magzoub, A.M., Naser, E.B., Jalal, A.B., Omran, F.O. 2013. Rotavirus infection among Sudanese children younger than 5 years of age: a cross sectional hospital-based study. Pan African Med. J., 16: 88.

Ebtihag, E.M., Ali, Y.H. 2011. Epidemiology of rotavirus caused diarrhoea in infants in Oman. J. Sci. Technol., 12(4): 74-81.

Erin, M.K., Reina, M.T., Melissa, L.A., Salvador, G.J., Roger, I.G. 2004. The epidemiology of rotavirus diarrhea in Latin America. Anticipating rotavirus vaccines. Pan Am. J. Public Health, 16(6): 371-377.

\section{How to cite this article:}

Kavitha, D., Kanimozhi, K. and Pannerselvam, A. 2016. Prevalence of Rotavirus Acute Gastroenteritis in Infants. Int.J.Curr.Microbiol.App.Sci. 5(3): 454-458. doi: http://dx.doi.org/10.20546/ijcmas.2016.503.053 